\title{
Investigating Aid Effectiveness in Developing Countries: The Case of Nepal
}

\author{
Yashoda Karki $^{1(\bowtie)}$ and Ilias O. Pappas ${ }^{1,2}$ (D \\ ${ }^{1}$ University of Agder, Kristiansand, Norway \\ \{yashoda.karki, ilias.pappas\}@uia.no \\ ${ }^{2}$ Norwegian University of Science and Technology, 7491 Trondheim, Norway
}

\begin{abstract}
Foreign aid serves as an important source of capital for any developing or under-developed country. It is very important to see how the recipient country can utilize this aid in the economic upliftment of the nation. Taking a case of Nepalese economy, this paper investigates the effectiveness of foreign aid in developing countries. The result from Johansen's cointegration test reveals that foreign aid independently is not adequate for the economic growth. Increased capital and technological infrastructures, improved skills on human capital, on the other hand, significantly changes the result for the positive aid impact on growth in the long run. Therefore, we can conclude that a good policy environment helps increase the aid effectiveness. However, the prevailing trade policy in the country is negatively affecting the aid effectiveness due to the extremely increased trade deficit. In the short-run, there is a negative impact of aid on growth.
\end{abstract}

Keywords: Foreign aid $\cdot$ Economic growth $\cdot$ Cointegration $\cdot$ Error correction model $\cdot$ Developing countries $\cdot$ Nepal

JEL Classification: $\mathrm{C} 01 \cdot \mathrm{F} 35 \cdot \mathrm{O} 47$

\section{Introduction}

Initially, foreign aid has been the most important source of external finance for developing countries to meet the basic human needs, infrastructure development in accordance with nation building. Aid was channeled through capital transfers and investment projects to overcome the capital shortage which hindered development in many nations. Several growth-oriented aid programs were initiated including poverty reduction, military development, educational upliftment, etc. [1]. The lack of countries' internal savings is one of the motivations for foreign aid donors to take part in the assistance. Over time, the focus of such aid has been changed to the macroeconomic stabilization, structural adjustment and debt reduction, political and economic transition, poverty reduction and social infrastructure. Past few decades, the donors started to put more emphasis on performance-based aid allocation, focusing on the global health, governance and security [2] and sustainable development goals. For the creation and development of sustainable and prosperous societies, all the actors in the society play an equally important role [3]. Foreign aid helping each sector of the societal 
development is an important factor for the attainment of sustainability and therefore the aid effectiveness has become a widespread topic of discussion.

The main objective of this paper is to analyze how effective foreign aid is to contribute on the recipient country's economic growth. We investigate the aid effectiveness taking a case of Nepalese economy. Being one of the least developed countries in the world, Nepal is highly dependent on foreign aid. The country has been deploying foreign aid both as aid for budget support and non-budgetary aid for over six decades. However, the Ministry of Finance reports show that the share of foreign aid on the government's total budget has been declining by the improved mobilization of domestic resources which shows that the country is transforming into a self-reliant economy.

There is evidence that foreign aid has negative impact on growth or the country's economic growth $[4,5]$. However, donors continue to disburse aid. One of the reasons for such disbursement could be that the real aim of granting aid to the recipient might not be to increase growth in many instances. "Part of aid is disbursed to alleviate human disasters in the wake of natural catastrophes. Other parts might directly be granted to increase consumption of the poor in recipient countries" The strategic interests of the donor have always been relevant in giving foreign aid [6]. The aid effectiveness study covering the period of 1983-2002 for Nepal has found that foreign aid has a positive and statistically significant effect on per capita real GDP in the long run but a negative impact in the short run. The aid effectiveness is increased in the presence of good policy environment [7]. Another recent contribution on the aidgrowth literature for Nepal covers the period until 2008 which finds the similar results on aid effectiveness [8].

The study for aid effectiveness in Bangladesh shows marginal effect of aid on GDP growth [9]. "Foreign grants mostly finance non-productive civil expenditures, but foreign loans generally finance public investment projects and human capital building programs, which eventually lead to higher output growth" [9]. Several cross-country panel estimations have found the evidence of positive aid effectiveness $[10,11]$. Foreign aid, however, depends on the aid apparatus. The adaptability of foreign aid, availability, and know-how of the latest technology is something that needs to be considered for aid to be effective in future [5]. The next section of the paper discusses the data and methodology used in the study followed by model specification and selection of policy variables. The rest of the paper consists empirical results, their implication and discussions with some concluding remarks.

\section{Methodology}

The annual time series data for Nepal from 1983 to 2013 have been used in this study. All the data are downloaded from publicly available online databases (World Bank; WDI, FRED, OECD; IDS and Ministry of Finance, Nepal). Since many time series data follow non-stationarity nature, in most of the cases, the regression result obtained from such series are spurious and are not good enough to use in economic and financial decision making. However, with cointegration, there is no problem of spurious regressions and the result obtained are adequate despite of their non-stationarity 
nature. We have used Johansen's maximum likelihood estimation [12] and error correction model (ECM), suggested by [13] originally stated and proved by [14], to identify the long-run and short-run relationship among the variables.

\section{Model Specification and Policy Indicators}

Based on the neo-classical production function, we estimate the following model:

$\ln R G D P P_{t}=\theta_{1}+\theta_{2} \ln G C F R_{t}+\theta_{3} \ln A R_{t}+\theta_{4} \ln E D U_{t}+\theta_{5} \ln M O N R_{t}+\theta_{6} \ln B D R_{t}+\theta_{7} \ln T R_{t}+u_{t}$

where, ln is the natural logarithm, RGDPP is the per capita real GDP, GCFR is the gross capital formation as a percentage of GDP, AR is aid/GDP ratio, EDU is secondary level school enrollment. the policy variables MONR is broad money supply (M2) to GDP ratio, BDR is budget deficit as a percentage of GDP and TR is trade as a percentage of GDP. Similarly, $\theta_{i}$ is the parameters that explain the elasticity of dependent variable related to independent variables, $u_{t}$ is the random error, $\ln$ represents natural logarithm, and the subscript $t$ represents time.

The data we are using has relatively a shorter time period, therefore, we have a smaller number of observations. To avoid degree of freedom problem, we have only taken two policy variables at a time in conducting Johansen's cointegration test in the following section.

\section{Empirical Results}

To conduct cointegration, it is a prerequisite that all the series to be included in the model must be integrated of same order. For example, if a non-stationary series becomes stationary after differentiating the series once, then the series is said to be integrated of order 1 or I(1). Similarly, if the series is stationary itself then it is $\mathrm{I}(0)$. Therefore, it is necessary to test for stationarity of the series to check if the series are integrated of same order or not.

Table 1. Phillip-Perron unit root test results

\begin{tabular}{|c|c|c|c|c|}
\hline \multirow[t]{2}{*}{ Variables } & \multicolumn{2}{|c|}{ Constant only } & \multicolumn{2}{|c|}{$\begin{array}{l}\text { Constant and time } \\
\text { trend }\end{array}$} \\
\hline & Level & $1^{\text {st }}$ difference & Level & $1^{\text {st }}$ difference \\
\hline $\operatorname{lnRGDPP}$ & -0.364 & $-7.177 * * *$ & -3.419 & $-7.139 * * *$ \\
\hline $\ln \mathrm{AR}$ & -1.687 & $-6.344 * * *$ & -2.347 & $-6.387 * * *$ \\
\hline $\operatorname{lnTR}$ & -1.553 & $-4.044 * * *$ & -1.299 & $-4.131 * *$ \\
\hline $\operatorname{lnMONR}$ & 0.558 & $-5.387 * * *$ & -3.240 & $-5.387 * * *$ \\
\hline $\operatorname{lnEDU}$ & -0.814 & $-3.700 * *$ & -2.131 & $-3.634 * *$ \\
\hline lnGCFR & -0.535 & $-6.630 * * *$ & -2.182 & $-6.575 * * *$ \\
\hline $\operatorname{lnBDR}$ & -1.078 & $-4.589 * * *$ & -2.724 & $-4.394 * * *$ \\
\hline
\end{tabular}

Note: $(* * *, * *$ significant at $1 \%, 5 \%)$ 
We have followed the Phillips-Perron (PP) test [15], which provides more robust estimates despite the series having serial correlation or any structural breaks. The results from PP test in (Table 1) show that all variables show stationarity either at 5\% or $1 \%$ significance level. While, all the variables are integrated of order 1, i.e., I(1), our variables are ready to test for cointegration.

\section{Johansen's Cointegration and Error Correction Model}

Johansen's likelihood ratio test has been performed to check if there exists any cointegrating relationship between the variables. First, only per capita real GDP and aid variable have been taken to see how the foreign aid would impact on the economic growth. The trace statistics suggest that there is one cointegrating vector, meaning that, there exists a long-run relationship between foreign aid and per capita real GDP (). The long-run coefficient for aid on tells us that there exists a significant negative impact of aid on per capita real GDP. This indicated that foreign aid independently, is not adequate for economic growth. The positive and significant error correction term implies an explosive model with no long-run convergence of any disequilibrium.

For the developing countries like Nepal, foreign aid is playing an important role to meet the shortfall in revenue as it is found to be used as a source of revenue in the government budget. This somehow relaxes the government budget constraint. Aid, nonetheless, should not be used only to meet the non-development expenditures. Aid has a stronger positive impact on non-development expenditures than on development expenditures of Nepal [16]. Here we can get an idea that a greater portion of aid could have been used in non-development expenditures which typically do not help in the economic growth of a nation. According to the OECD data, we see that the percentage of grants on foreign aid to Nepal is more than the percentage of loans. Foreign grants mostly finance non-productive public expenditures while loans are used in public investment projects [9] therefore foreign loans can raise GDP, but grants don't. Therefore, foreign aid being highly used in public expenditures than in developmental activities, we can conclude that foreign aid does not help in economic growth.

Introduction of control variables in the model remarkably changes the result. The impact of aid on per capita real GDP is significantly positive in the long-run while taking the variable for capital and school enrolment in our existing model. This implies that, with the higher level of capital formation in-lined with enhanced technology and improved skills on human capital, foreign aid helps significantly to increase per capita real GDP in long-run. As shown in the second half of (Table 2) the significant negative error correction term indicates that any long-run disequilibrium is corrected within the current year at the adjustment speed of $2.8 \%$. In the short-run, aid has a negative and significant coefficient which signifies that there is a negative impact of aid on per capita real GDP in the short run. 
Table 2. Johansen's Likelihood ratio test estimates and long run normalized coefficients

\begin{tabular}{|c|c|c|c|c|c|c|}
\hline $\mathrm{H}_{0}$ & $\mathrm{H}_{1}$ & Eigenvalues & $\left(\lambda_{\text {trace }}\right)$ & $\begin{array}{l}\text { Critical } \\
\text { value }\end{array}$ & $\left(\lambda_{\max }\right)$ & $\begin{array}{l}\text { Critical } \\
\text { value }\end{array}$ \\
\hline \multicolumn{2}{|c|}{$\mathrm{VAR}=4$} & \multicolumn{5}{|c|}{ Variables: $\ln R G D P P$ and $\ln \mathrm{AR}$} \\
\hline $\mathrm{r}=0$ & $r=1$ & 0.40471 & 15.8798 & 15.41 & $14.005 * *$ & 14.07 \\
\hline$r \leq 1$ & $\mathrm{r}=2$ & 0.06708 & $1.8746^{* *}$ & 3.76 & 1.875 & 3.76 \\
\hline \multicolumn{2}{|c|}{$\mathrm{VAR}=4$} & \multicolumn{5}{|c|}{ Variables $\ln R G D P P, \ln A R, \operatorname{lnGCFR}$ and $\operatorname{lnEDU}$} \\
\hline$r=0$ & $r=1$ & 0.77986 & 69.6279 & 47.21 & 40.864 & 27.07 \\
\hline$r \leq 1$ & $\mathrm{r}=2$ & 0.51679 & $28.7638 * * *$ & 29.68 & $19.637 * * *$ & 20.97 \\
\hline \multicolumn{2}{|c|}{$\mathrm{VAR}=2$} & \multicolumn{5}{|c|}{ Variables $\operatorname{lnRGDPP}, \ln \mathrm{AR}, \operatorname{lnGCFR}, \operatorname{lnEDU}, \ln \mathrm{TR}$ and $\operatorname{lnMONR}$} \\
\hline$r=0$ & $r=1$ & 0.82570 & 125.8335 & 94.15 & 50.663 & 39.37 \\
\hline $\mathrm{r} \leq 1$ & $r=2$ & 0.67143 & $75.1704 * * *$ & 68.52 & $32.277 * * *$ & 33.46 \\
\hline$r \leq 2$ & $r=3$ & 0.51848 & $42.8931 * *$ & 47.21 & 21.194 & 27.07 \\
\hline \multicolumn{2}{|c|}{$\mathrm{VAR}=2$} & \multicolumn{5}{|c|}{ Variables $\ln R G D P P, \ln A R, \operatorname{lnGCFR}, \operatorname{lnEDU}, \ln T R$ and $\operatorname{lnBDR}$} \\
\hline$r=0$ & $r=1$ & 0.74513 & 97.8680 & 94.15 & 39.643 & 39.37 \\
\hline $\mathrm{r} \leq 1$ & $r=2$ & 0.50497 & $58.2246 * *$ & 68.52 & $20.391 * *$ & 33.46 \\
\hline \multicolumn{2}{|c|}{$\mathrm{VAR}=2$} & \multicolumn{5}{|c|}{ Variables $\ln R G D P P, \ln A R, \operatorname{lnGCFR}, \operatorname{lnEDU}, \operatorname{lnMONR}$ and $\operatorname{lnBDR}$} \\
\hline $\mathrm{r}=0$ & $\mathrm{r}=1$ & 0.70885 & 106.9048 & 94.15 & $35.783 * * *$ & 39.37 \\
\hline $\mathrm{r} \leq 1$ & $r=2$ & 0.63974 & $71.1215 * * *$ & 68.52 & 29.607 & 33.46 \\
\hline \multicolumn{2}{|c|}{$\operatorname{lnRGDPP}$} & 1.000 & 1.000 & & & \\
\hline \multicolumn{2}{|c|}{$\ln A R$} & $0.862 * * *$ & $-0.930 * * *$ & 0.014 & $0.579 * * *$ & $-0.083 * * *$ \\
\hline \multicolumn{2}{|c|}{ lnGCFR } & & $-1.280 * *$ & $0.122 * * *$ & 0.221 & $0.073 * *$ \\
\hline \multicolumn{2}{|l|}{$\operatorname{lnEDU}$} & & $-1.367 * * *$ & $-0.234 * * *$ & $-1.143 * * *$ & $-0.168 * * *$ \\
\hline \multicolumn{2}{|l|}{$\operatorname{lnTR}$} & & & 0.013 & $0.250 * * *$ & \\
\hline \multicolumn{2}{|c|}{ lnMONR } & & & $-0.537 * * *$ & & $-0.522 * * *$ \\
\hline \multicolumn{2}{|l|}{$\operatorname{lnBDR}$} & & & & $-0.351 * * *$ & $0.087 * *$ \\
\hline \multicolumn{2}{|l|}{ ECT } & $0.041 * *$ & $-0.028 * * *$ & -0.096 & 0.032 & -0.166 \\
\hline \multicolumn{2}{|c|}{$\Delta \ln R_{G D P P} P_{t-1}$} & $-0.531 * *$ & $-0.541 * * *$ & -0.122 & -0.159 & -0.152 \\
\hline \multicolumn{2}{|c|}{$\Delta \ln \mathrm{AR}_{\mathrm{t}-1}$} & $-0.040 * *$ & 0.017 & $-0.035 * * *$ & -0.045 & $-.045 * * *$ \\
\hline \multicolumn{2}{|c|}{$\Delta \operatorname{lnGCFR}_{\mathrm{t}-1}$} & & 0.009 & $0.057 * *$ & 0.050 & 0.046 \\
\hline \multicolumn{2}{|c|}{$\Delta \operatorname{lnEDU} \mathrm{t}_{\mathrm{t}-1}$} & & -0.017 & -0.022 & -0.017 & -0.034 \\
\hline \multicolumn{2}{|c|}{$\Delta \operatorname{lnTR_{\mathrm {t}-1}}$} & & & -0.042 & -0.041 & \\
\hline \multicolumn{2}{|c|}{$\Delta \operatorname{lnMONR}_{\mathrm{t}-1}$} & & & 0.089 & & 0.066 \\
\hline \multicolumn{2}{|c|}{$\Delta \operatorname{lnBDR} \mathrm{t}_{\mathrm{t}-1}$} & & & & -.016 & -0.018 \\
\hline \multicolumn{2}{|c|}{$\begin{array}{l}\text { Serial } \\
\text { correlation }\end{array}$} & $(0.815)$ & $(0.903)$ & $(0.473)$ & $(0.850)$ & $(0.811)$ \\
\hline \multicolumn{2}{|c|}{$\begin{array}{l}\text { Jarque-Bera } \\
\text { test for } \\
\text { normality }\end{array}$} & $\begin{array}{l}2.124 \\
(0.713)\end{array}$ & $\begin{array}{l}12.773 \\
(0.119)\end{array}$ & $\begin{array}{l}7.736 \\
(0.805)\end{array}$ & $\begin{array}{l}10.880 \\
(0.539)\end{array}$ & $\begin{array}{l}7.851 \\
(0.796)\end{array}$ \\
\hline
\end{tabular}

Note: $(* * *, * *$ significant at $1 \%, 5 \%$ respectively)

The negative effect of aid in per capita real GDP is due to the less absorptive capacity of the country. The aid allocation may not be completed promptly because of the involvement of too many agencies which might lead to role mismatch and lack of 
coordination among them. Due to a poor bureaucracy, the development budget of the country is being frozen. In such circumstances, it is obvious that aid receipts are not being utilized immediately. The longer time taken to utilize the disbursed aid is also because of the aid conditionalities.

Considering the policy variables, the results from first two estimates having trade component in the model support the evidence that there is significantly negative impact of aid on per capita real GDP in the long run. One possible situation that trade leads to negative aid impact on economic growth is when the economy is facing a higher trade deficit. The Ministry of Finance data from Nepal exhibits that Nepal is having trade deficit in an increasing trend over the past two decades. The combination of policy variables money supply and budget deficit in the model, however, provides the evidence in favour of positive long-run impact of aid on per capita real GDP. On the other hand, all three different combinations of the policy variables in the model suggests that there is significant negative aid effect in the short run.

The serial correlation and normality do not seem to be a problem in all the models we have tested. The VECM diagnostic tests presented in the last section of (Table 2) explains that there is no autocorrelation in the variables and the random errors follow a normal distribution for all the equations in our model. This indicates that the variables used in the models explain the relationship very well in all cases.

\section{Conclusion}

Foreign aid serves as an important source of fund for developing and under-developed countries. There have been countless arguments over the period on whether aid has been utilized effectively for the economic upliftment and growth of the recipient countries [7, 8]. Taking a case of Nepal, we have been analyzed the effectiveness of aid in the economic growth of developing countries. The results show that foreign aid independently is not adequate for economic growth. The higher level of capital formation in-lined with enhanced technology and improved skills on human capital significantly increases the aid effectiveness. Aid effectiveness increases when the macroeconomic indicators show an improvement resulting in an enhanced economic situation. There is a negative impact of aid on per capita real GDP in the short run which is because of ineffective aid monitoring, problems related to aid management and aid conditionalities.

The country's monetary policy and fiscal policy, measured in the form of broad money supply and government budget status, are supportive on positive aid effectiveness. However, the prevailing trade policy is negatively affecting the aid effectiveness due to high trade deficit. Current status of trade in the economy is impeding foreign aid to be utilized in the targeted sector. The policy should be reviewed so that the size of ever-increasing trade deficit reduces. Similarly, foreign aid should be monitored strictly in order that its goal is fulfilled. A sudden increase in remittance, resulting in a culture of dependency, also fuels up the trade deficit which directly or indirectly reduces aid effectiveness. However, further investigation should be carried out to draw a conclusion on how remittance affects the effectiveness of foreign aid. Although one of the main objectives of this study was to research on the latest 
economic activities, it was not possible to cover the recent years because of the lack of data. This restricted the outcome of the paper as we were not able to see the most recent impact of aid on the growth.

\section{References}

1. Paul, E.: A survey of the theoretical economic literature on foreign aid. Asian-Pac. Econ. Lit. 20, 1-17 (2006)

2. Akramov, K.T.: Foreign Aid Allocation, Governance, and Economic Growth. University of Pennsylvania Press, Philadelphia (2012)

3. Pappas, I.O., Mikalef, P., Giannakos, M.N., Krogstie, J., Lekakos, G.: Big data and business analytics ecosystems: paving the way towards digital transformation and sustainable societies. Inf. Syst. e-Bus. Manag. 16(3), 479-491 (2018). https://doi.org/10.1007/s10257018-0377-z

4. el Hamid Ali, H.A.: Foreign aid and economic growth in Egypt: a cointegration analysis. Int. J. Econ. Finan. Issues 3, 743-751 (2013)

5. Rajan, R.G., Subramanian, A.: Aid and growth: what does the cross-country evidence really show? Rev. Econ. Stat. 90, 643-665 (2008)

6. Bandyopadhyay, S., Vermann, E.K.: Donor motives for foreign aid. Federal Res. Bank St. Louis Rev. 95, 327-336 (2013)

7. Bhattarai, B.P.: Foreign aid and growth in Nepal: an empirical analysis. J. Dev. Areas 42, 283-302 (2009)

8. Sharma, K., Bhattarai, B.: Aid, policy, and growth: the case of Nepal. J. Econ. Issues 47, 895-910 (2013)

9. Quazi, R.M.: Effects of foreign aid on GDP growh and fiscal behavior: an econometric case study of Bangladesh. J. Dev. Areas 38, 95-117 (2005)

10. Moolio, P., Kong, S.: Foreign aid and economic growth: panel cointegration analysis for Cambodia, Lao PDR, Myanmar, and Vietnam. Athens J. Bus. Econ. 2, 417-428 (2016)

11. Qayyum, U., Haider, A.: Foreign aid, external debt and economic growth nexus in lowincome countries: the role of institutional quality. Pak. Dev. Rev. 51, 97-115 (2012)

12. Johansen, S., Juselius, K.: Maximum likelihood estimation and inference on cointegrationwith applications to the demand for money. Oxford Bull. Econ. Stat. 52, 169-210 (1990)

13. Engle, R.F., Granger, C.W.: Co-integration and error correction: representation, estimation, and testing. Econ. J. Econ. Soc. 55, 251-276 (1987)

14. Granger, C.W., Weiss, A.A.: Time series analysis of error-correction models. In: Studies in Econometrics, Time Series, and Multivariate Statistics, pp. 255-278. Elsevier (1983)

15. Phillips, P.C., Perron, P.: Testing for a unit root in time series regression. Biometrika 75, 335-346 (1988)

16. Bhattarai, B.P.: Foreign aid and government's fiscal behaviour in Nepal: an empirical analysis. Econ. Anal. Policy 37, 41-60 (2007) 